\title{
The effectiveness of human resource information system through employee satisfaction and the system usage
}

\author{
Jazari Abdul Hamid ${ }^{1}$, Johannes ${ }^{2}$, Syahmardi Yacob ${ }^{3}$, Edward ${ }^{4}$ \\ ${ }^{1}$ Doctoral Program in Economics and Business, Universitas Jambi, Indonesia \\ 2,3,4 Faculty of Economics and Business, Universitas Jambi, Indonesia \\ Corresponding author:jazari@live.com
}

\begin{abstract}
Nowadays, information technology is essential for every organization to achieve effective and efficient business processes. Being practical and efficient indicates that a business venture is in the right direction, as human resource management makes decisions to achieve the goal. This study explores the concept of user satisfaction and system use of human resource information systems by analyzing the effectiveness and efficiency of the system. Besides using methods such as system usage and information usage, the writer also explores digitalization and digital mindset to analyze system usage and user acceptance (satisfaction) as an indication to achieve efficiency and effective operation. The review concludes that the information system is essential for individuals and organizations in every day of operational activities. Some models are completed research but not developed in activities, efficiency, and digital mindset to explore satisfaction of system. The study suggests that digitalization can also be a tool for conception to the current information system and system dan system usage of human resource information. Finally, we can say that this model suggests a combination of user satisfaction, quality system, and quality information model or concept supported by digitalization (namely mindset) to support the effectiveness of the human resource information system.
\end{abstract}

Keywords: Human resource information system; technology; effectiveness; efficient

\section{INTRODUCTION}

The role of technology is significant for life until it is already in the decade of digitalization. Its functions are very prominent the higher and the latest technology development. It must analyze the ability to create effectiveness and efficiency so that the product or service is famous among the current innovations in various sectors, business and non-business, and products and services. Its huge role is mainly to trim the system and shorten the flow of business processes in every organization's business function.

Part of the business process, for example, in the management of human resources, is fixed in three major devices with the terms information, technology, and communication (ICT), which includes hardware and software, and network communication. The source information system facilitates the management of the database into meaningful information for the user (user); because of the high speed, it is connected between user units through various types of networks up to the hand. Mobile phones with Android, IOS, and Windows operating system applications are increasingly dynamic and responsive regardless of distance, time, place, or size.

\footnotetext{
${ }^{1}$ Student of University of Jambi, Doctoral Program, email: jazari@live.com

2 Economic Department, Universitas Jambi, Indonesia

${ }^{3}$ Economic Department, Universitas Jambi, Indonesia

${ }^{4}$ Economic Department, Universitas Jambi, Indonesia
} 
Human resource information technology has become a strategic tool, where its functions and roles are more comprehensive and more broadly related to the company's vision, mission, and goals. However, not all fields and organizations have used human resource information technology effectively and efficiently. Many applications fall and grow as the effectiveness or efficiency of the application increases or decreases. It is no different from the human resource management application known as the human resource information system (HRIS) that has been operating effectively and efficiently. On this occasion, we would like to review the theory and implementation of HRIS in terms of effectiveness and efficiency.

The objective of this review is to:

1. Elaborate the grand theory and derivative ideas related to human resource management

2. To Elaborate journals and scientific papers to understand the theoretical condition and novelty of the latest human resource information management

3. To propose the new concept of effectiveness and efficiency through a human resource information system.

Measuring the success of HRIS will be seen from the effectiveness and efficiency of the information system; the indication is called the quality of the information system, namely the usefulness of the information (system use). Therefore, measuring the benefit of information systems through measures of success or effectiveness is critical to understanding the value and significance of management actions or strategies (DeLone \& McLean, 2004).

In addition to measuring the effectiveness of HRIS from the usefulness of information, it can also be seen from user satisfaction. The smooth use of users (users) who help in carrying out organizational tasks and satisfaction with the benefits of the system itself. HRIS can encourage high-performing organizations and users or employees who use the system every day at work (Hellstén and Markova, 2003).

The success of an HRIS if the benefits of the information system can be felt for him as a direct user. Users themselves are part of the information system because employee personal information is recorded and updated, either by themselves or by the administrator. Therefore, one indicator of whether users feel the benefits or success of the system is helping them in carrying out their work which is marked by increased employee performance.

In detail, the perception of users of human resource information systems is to measure several dimensions as factors that influence individual perceptions of human resource information systems. Based on the research model of information systems, the characteristics of individuals, organizations, and the design itself, user satisfaction, and system usability have been formulated by(Bakke et al., 2008) that effectiveness of human resource information management, system usage, and user satisfaction.

\section{LITERATURE REVIEW}

\section{The Concepts of Human Resource Information System}

Technology is defined by various terms (Carolina, 2015). Terms that are increasingly popular because of the latest technological developments are digitalization, digital transformation, and industry 4.0 as parts that form a physical human resource information system and a digital mindset, which is the initial part of the review.

\section{a. Information technology}

Information technology as "The application of science, especially to industrial or commercial objectives, and t scientific method and material used to achieve a commercial or industrial purpose (R. E. Indrajit, 2000). Electronic or digital products are considered as a 
group: a store specializing in office technology. While in Anthropology, the body of knowledge available to society is of use in fashioning implements, practicing manual arts and skills, and extracting or collecting materials (Afolayan \& Falola, 2017).

The diversity of definitions of information technology influences the design and outcomes of research, negotiations around transfers, and government policy in general (Lei \& Jing, 2016). The term technology, according to Kumar et al. (Kulviwat et al., 2007), consists of two main components: 1) physical components such as products, tools, equipment, blueprints, techniques, and processes; and 2) an informational component consisting of knowledge in the fields of management, marketing, production, quality control, reliability, skilled labor, and functional areas.

The technology definition regards technology as a 'configuration,' observing that the object of transfer (technology) depends on a set of subjectively defined but determinable processes and products (Bukht \& Heeks, 2018). Current studies on technology transfer have linked technology directly to knowledge, and more attention has been paid to the research and development process (Çelo \& Dumi, 2013).

We can say that two primary components can be identified: 1) 'knowledge' or something.' 2) 'do something.' Technology is always associated with obtaining specific results, solving problems, completing certain tasks using skills knowledge, and exploiting assets (Agarwal \& Prasad, 1998). The technology concept is related to the technology contained in the product and related to knowledge or information about the use, application, and process in developing the product (Hall \& Frcpc, 2012).

The early concept of technology as information stated that technology is generally applicable and easy to reproduce and reuse (Arrow, 1969) argues that the earlier idea of technology contradicts the strand of literature on international technology transfer, which argues that "technology is understood as firm-specific information regarding the characteristics and performance properties of the production process and product design.".

(MacKenzie \& Wajcman, 1965) define technology as integrating physical objects or artifacts, creating things, and the meanings associated with physical objects. These elements are not distinguishing and separable factors but form the 'borderless network' that constitutes technology (Woolgar, 1985).

The latest definition by (Maskus, 2004) expands the concept of technology where technology is defined as 'information needed to achieve a particular production result from a sure way to combine or process selected inputs which include production processes, intra-firm organizational structures, management techniques, and financial means, marketing methods or a combination thereof.

Other scholars (Skulski 2020) suggest that technology as a cultural system is related to humans' relationships and environment. From a systems perspective, Afriyie (1988) defines technology which includes: 1) knowledge sub-systems; technical support system (software); and 3) capital technology (hardware).

In addition to understanding the concept of technology, technology classification is also fundamental in explaining the various technologies contained in the company's products, production processes, and human resources. (Reddy et al., 2020), in their extensive review of the technology transfer literature, they have constructed a technology taxonomy from the previous literature.

An early taxonomy of technology was developed by (Edwin Mansfield, 1975)e, who used the classification of "embodied" and "intangible" technologies. This classification was further extended by (Meyer 2003) to include embodied capital, embodied and intangible technologies. (Madeuf, 1984) suggest the use of technology classifications "embodied in the 
product," "embodied in the process," and "embodied by people" rather than classifications based on "general," "system-specific," and "enterprise-specific" technology.

(Skulski, 2020) constructed a technology taxonomy by separating product design, engineering production, and managerial functions. (Madeuf, 1984) points out the difference between "alienated" technology and "socialized" technology. Isolated technologies include non-free information such as confidential knowledge. On the other hand, "socialized technology" does not imply any special transaction.

b. Information system

Since the mid-1970s, there has been an increasing need for computer-based personnel management systems, which previously only relied on hardcopy, which took a long time (Prof. R. E. Indrajit, 2016). The system itself has the meaning of something that allows personnel management to manage people efficiently and effectively and provide more positive services for the organization (Carolina, 2015).

The term information technology was introduced in the mid-1980s, which is the development of computer technology combined with telecommunications technology. The definition of information technology itself has been internationally agreed upon as a result of data processing which in principle has more value than raw data, which is the raw material of information. Telecommunications technology has made the world feel smaller (reducing space and time). Information technology is a technology related to processing data into information and transferring the data/information within the boundaries of space and time (Indrajit 2016).

\section{c. Human resource information system}

Human resource information system or the so-called human resource information system (HR information system) is defined as consisting of databases, computer hardware, and software applications for collecting, storing, managing, transmitting, retrieving, and manipulating data for the benefit of human resource management matters. Mohanti explained that the human resource information system is designed to link operations with human resource systems (Madhuchhanda \& Kumar, 2009).

In line with that, Tannebaum defines more clearly that "the human resource information system is the system used to acquire, store, manipulate, analyze, retrieve and distribute pertinent information regarding and the organization's human resource" (Tannenbaum, 1990). He did not mention applications, hardware, and software. Currently, the development of information technology is quite rapid, especially the internet as a medium that can accelerate access to information systems, both through open sources and intranets.

\section{d. The beneficial of human resource information system}

The number of large enough employees will not be possible to be managed manually. Likewise, because of the location, with the company's development and its branches, it is impossible to manage human resources manually without a reliable information system. Therefore, management information systems are very important for organizations, especially large organizations, in creating company efficiency.

To deal with the increasing amount of information that requires classification, reclassification, and cross-classification of information (Yahaya et al., 2018). Currently, a formal human resource management information system to collect, store, maintain, retrieve, and validate data by an organization about resources. Human resource management information system is part of a larger management information system (R. E. Indrajit, 2000).

\section{e. Human resource information strategy}


The human resource information system model emphasizes the role of human resource management information systems as a link between the strategic vision of the organization and the implementation of human resources (Lim et al., 2008). A human resource information system that has a good design in line with the objectives of the HR department itself can provide services as the main management tool for long-term strategic planning decisions (Madhuchhanda \& Kumar, 2009).

The information system model is derived based on the company's vision, mission, and values. Then the three strategic directions are derived into strategic goals to be achieved. To achieve the strategic objectives, a key performance indicator (KPI) is needed, which is carried out in two ways: through business strategies and information technology strategies to give birth to a tactical procedure that is useful for carrying out daily tasks. As for the flow of the strategic position of the company's information system and is the forerunner of the human resource information system.

Furthermore, (R. E. Indrajit, 2006) explains where the information technology strategy comes from, which is based on five main inputs, namely:

- A business strategy, which is a document that must be used as the main basis for making an IT Strategy because the document mentions the vision and mission of the organization.

- Business trend, everything related to the trend of business patterns that will occur in the future in a particular industry.

- Competitor analysis is an activity that must be carried out considering that the strategy is basically made because of competitors.

- IT trend aims to avoid mistakes in selecting technology that is applied and developed within the company.

- Existing IT, namely the configuration and specifications of the technology currently available.

The position of human resource technology information systems is crucial and vital in the company's strategic direction. There are three kinds of assets owned by information technology systems, human assets, relationship assets, and technology assets which are the key to maintaining long-term competitive advantage. This can make more possible to achieve effectiveness and efficiency to reach a successfull company. This can be viewed from the effectiveness from with several indicators, especially the assessment of organization, user or users, and the information system itself related to the dimension of individual, organization, and the system as a successful form of a human resource information system.

\section{Digital, Digitizing, and Digital Transformation}

\section{a. Digitization}

The advent of commercially available high resolution (600 DPI or more) paper scanners in the late 1990s was the technical trigger for the mass conversion of analog data (paper archives) to digital formats. The invention of the first compact disk (CD) in 1982 offered inexpensive storage, and distribution medium used not only for storing paper documents but also for converting analog audio and video formats, such as LPs, cassettes, film reels, and VHS cassettes. The digitization of microfilm and microfiche was also rampant at that time. This conversion may not provide the promised longevity of the new digital formats (TIFF, $\mathrm{Dj} V u$, PDF), but it does provide other benefits, such as usability, speed of access, transferability, and the possibility of further processing (Savic, 2019).

An example is the International Nuclear Information System (INIS). From its founding in 1970 to 1996, INIS collected and modified the microfiche of more than 312,000 non- 
conventional literature reports (NCL) received from member countries of the IAEA (International Atomic Energy Agency) and international organizations. The microfiche collection contains more than 1 million items, with an estimated 25 million full text pages. This collection, after digitization, is now part of the online INIS repository.

\section{b. Digitalization}

Digitization has three distinct phases - the initial phase, when a single operation or process is automated (such as purchasing a library); the middle phase, when related processes are automated and bundled together (such as library collection management or supply chain management); and the third, the most complex phase, when several systems that support business processes and information flows are integrated into a library management system or enterprise management system.

While early digitization was a major concern of data and various converters, digitization concentrated on the automation of various business processes and operations, as well as information processing. IT hardware and software was powerful enough at the time to allow automation of existing digital work processes and creation of entirely new ones. Huge investments were made in purchasing, developing, deploying and maintaining a conglomerate of disparate applications that tackled many single problems using sometimes unrelated technologies that barely "talked" to each other, but helped IT departments disband.

DIGITIZATION

\begin{tabular}{|c|c|c|c|}
\hline Focus & Data conversion & Information processing & Knowledge leveraging \\
\hline Goal & Change analog to digital format & $\begin{array}{l}\text { Automate existing business } \\
\text { process operations and } \\
\text { processes }\end{array}$ & $\begin{array}{l}\text { Change company sculpture, the } \\
\text { way it works and thinks }\end{array}$ \\
\hline Activities & $\begin{array}{l}\text { Convert paper documents, photo, } \\
\text { microfilm, LPS, Films, and VHS } \\
\text { tapes to digital format }\end{array}$ & $\begin{array}{l}\text { Creation of completely digital } \\
\text { work processes }\end{array}$ & $\begin{array}{l}\text { Creation of a new digital company } \\
\text { or transformation to a digital one }\end{array}$ \\
\hline Tools & $\begin{array}{l}\text { Computers and } \\
\text { conversion/encoding equipment }\end{array}$ & $\begin{array}{l}\text { IT systems and computer } \\
\text { applications }\end{array}$ & $\begin{array}{c}\text { Matrix of new (currently disruptive) } \\
\text { digital technologies }\end{array}$ \\
\hline Challenge & $\begin{array}{l}\text { Volume } \\
\text { Material }\end{array}$ & $\begin{array}{c}\text { Price } \\
\text { Financial }\end{array}$ & $\begin{array}{l}\text { Resistance to change } \\
\text { Human resource }\end{array}$ \\
\hline Example & $\begin{array}{l}\text { Scanning paper-based } \\
\text { registration forms }\end{array}$ & $\begin{array}{l}\text { The completely electronic } \\
\text { registration process }\end{array}$ & $\begin{array}{l}\text { Everything electronic, from } \\
\text { registration to content delivery }\end{array}$ \\
\hline
\end{tabular}

Figure 1: Digitization, Digitalization, Digital Tranformation (Savic, 2019)

\section{c. Digital transformation}

Digital transformation is a transformation process that requires a drastic transition from conventional business processes to digital business processes. In short, it is not limited to business processes, but we turn our company's services into user-friendly services. In its application, digital transformation can be carried out in various types of technology massively, such as data analytics, automation, cloud computing, and several other services that we will introduce to you one by one.

We need to know that using impractical processes, many procedures to complete, and require high-cost systems will no longer compete with businesses without using digital technology, which in the huge process come with digital transformation. However, this occurs 
if there is a change in the digital mindset. Digital is about people as well as technology. In the digital age, efficiency is about seamlessly bringing people and technology together. Therefore, an important part of operating in today's landscape is to have a 'Digital mindset', capable of incorporating technology into their everyday roles and extracting value from it.

The digital mindset is not just the ability to use technology. Rather, it is a set of attitudes and behaviors that enable people and organizations to forecast contingencies. Social Media, Big Data, Mobility, Cloud, AI and Robotics are some of the great digital forces that disrupt and deconstruct today's world, permeating every aspect of life and business. For organizations to thrive, they must be able to create and implement business strategies that take into account the profound changes these forces are bringing about.

Organization, however, is about people. Therefore, for an organization to be successful, it must have the right people; and digital organizations need people with a digital mindset, characterized by the ability to:

- understand the power of technology to democratize teams and processes.

- adapt to the scale of output and accelerate every form of interaction and action.

- understand the impact of linkages.

- deal with changes and disturbances with equanimity.

\section{d. Digital Mindset}

Digital mindset requires not only be able to be savvy but also behave. Rather, it is a set of attitude and behavior enabling people and organization forecast contingencies. Social media, big data, mobility, cloud computing, artificial intelligent, and robotics are some of the great digital forces that disrupt and deconstruct today's world, permeating every aspect of life and business. For organizations to thrive, they must be able to support implementing business strategies taking into account the profound changes these forces are bringing about.

Organization, however, is about people. For an organization to be successful, it must have the right people that is the digital organization which has people with a digital mindset, characterizing the ability to:

- Understand the power of technology to democratized teams and processes.

- Adapt to the scale of output and accelerate every form of interaction and action.

- Understand the impact of linkages.

- Deal with changes and disturbances with equanimity.

It is very important to highlight that digital literacy is not the same as having a digital mindset. Being digitally savvy simply demonstrates an individual's ability to use certain technologies and allows them to develop a digital mindset more seamlessly, if they are willing to do so. In the digital age, however, not choosing to develop a digital mindset leads to catastrophic impacts.

\section{DISCUSSION}

\section{a. Success Model and System Usage Condition}

The model used in this study is the requirements for a successful human resource management information system, proposed by (Haines and Petit 1997) as shown in Figure 1 below. The proposition is developed in a simple but inclusive model consisting of three sets, namely (1) individual/task, (2) organizational, and (2) system and two dependent variables. Most of the independent variables in the model are prerequisites for the success of the system.

The above model (Haines \& Petit, 1997) make a simple proposition but an inclusive model consisting of three sets of antecedents, namely (1) user satisfaction and system usability, 
namely individual/task, organizational, system and two dependent variables, namely user satisfaction (user satisfaction) and system usage which are factors that are influenced by (1) individual/task, (2) organizational, and (3) system.

Firstly, individual characteristics are related to user satisfaction. When viewed from the characteristics of the task/individual, namely age, gender, education, job characteristics, work experience, computer experience, computer understanding..

Secondly, the variable organizational conditions are size (size of the organization), availability of internal user support (the existence of internal user support), organization computer experience (organizational computer experience).

Thirdly, the system has dimension user involvement, training, support, documentation, application development, dependent, online, access, number of applications, ease of use, and usefulness.

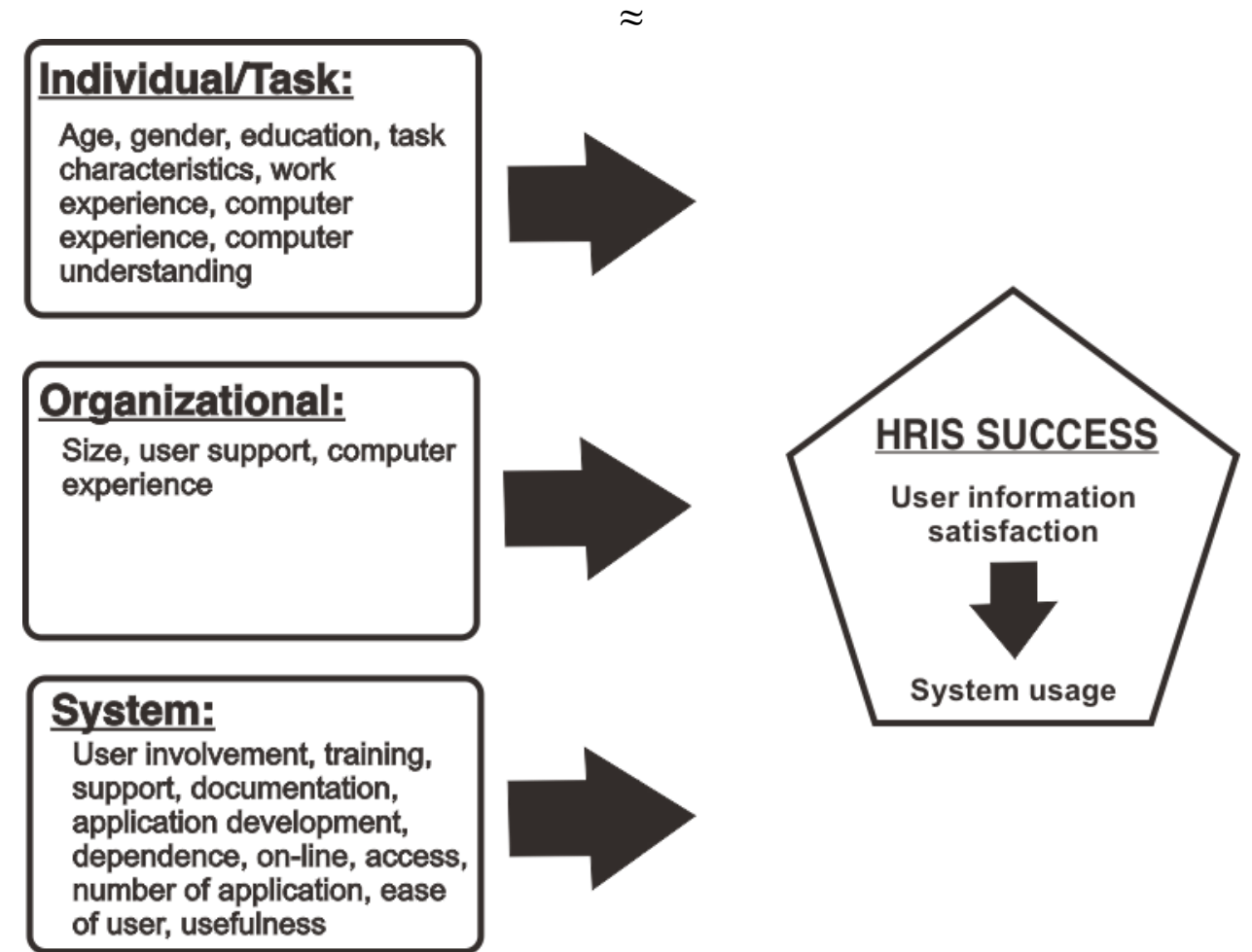

Figure 2: Technology Acceptance Model (TAM) (Haines \& Petit, 1997)

With data gathered from the Canadian Association of Human Resource Systems Professional (CHRSP) 152 users who interact with computer-based human resource information systems in carrying out their work with mostly average is 37 years, and they used human resource managers who worked at least five years. Respondents generally work in use at least eight applications related to human resources, and they are generally self-study.

The results showed that only a few individual variables were significantly related to user satisfaction and system usage. Among the most significant is the long work experience in the current position. Meanwhile, the difference between men and women was not significant, and the level of system usage. Variables such as age, education level, and work experience in the field of human resources and organizational fields do not affect user satisfaction or system use. The difference between respondents in the field of clerks, specialists, or managers was not significant for user satisfaction. However, it is significant for the use of the system.

In terms of organizational conditions, the size of the organization is not large enough to explain user satisfaction or system use. The time in the field of human resource information 
systems or the number of years the organization has used the system does not show a significant correlation with the use of the system. The size of the organization is not significant because small companies are less dependent on outside support. User satisfaction in the human resource information system unit or department is significant. This study suggests that the existence of internal support with the presence of a human resources information system department or unit has a considerable influence on user satisfaction and system use.

Training shows a significant relationship to satisfaction, and the more training intention, the higher the user satisfaction. However, when the respondent carried out the training, satisfaction was significantly reduced. As expected, there is a positive relationship between written, structured, and complete documentation and user satisfaction.

Regarding the system functionality category, the system performance category has a strong positive correlation between ease of use and user satisfaction. There is also a strong positive relationship between expected usability and user satisfaction. The weak relationship between the ease of using the system and the use of the system is related between these two variables.

In previous studies, the strength of the relationship between user satisfaction and system usage was not clearly explained. However, this study expects that user satisfaction will tend to use more systems. The correlation between the two dependent variables looks weak. Therefore, this study confirms that a higher the level of user satisfaction does not mean using the system more. However, the case at Bank Indonesia does not directly use HRIS every day, even though almost every day they have to log into the HRIS. This means that the influence on user satisfaction gradually becomes used to it. However, when compared to other information system facilities or from other institutions, the satisfaction is more visible.

There are also several studies to support research and strengthen the concept of Doll and Torkzadeh, such as that conducted by (Ilias et al., 2009) where they measure the level of satisfaction with the instrument that has been carried out by Doll and Torkzadeh thus strengthening the concept.

The next researchers develop a classification for the system as a system usage in influencing user satisfaction. The capital was developed by (Haines \& Petit, 1997) as a human resource information system model. It was built with a literature of more than 500 related articles. The components of the model consist of strategic integration, personal development, communication and integration, record and compliance, HR analysis, knowledge management,

\section{b. Model End-User Satisfaction}

(Ives et al., 1983) developed a user information satisfaction (UIS) instrument to measure users' general satisfaction with information provided by an organization's data processing group. However, they only emphasize the use of computers and data processing with a Likert scale of measurement due to instrument limitations (Torkzadeh's, 2010a).

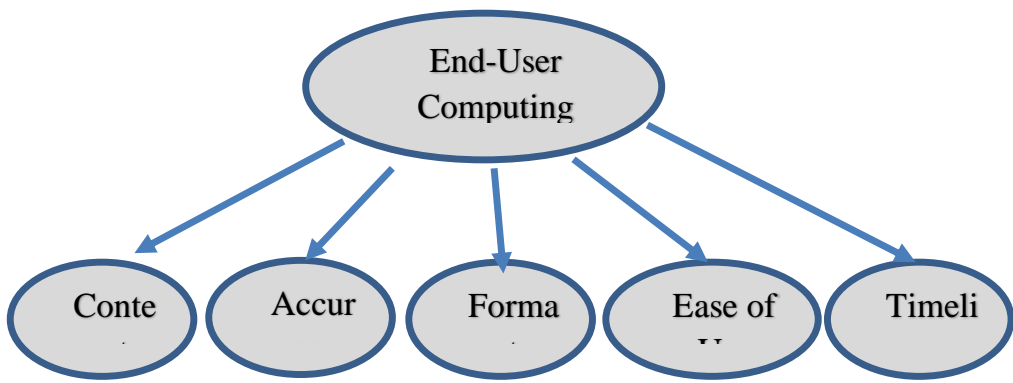

Figure 3: Model End User Computing Satisfaction Doll and Torkzadeh (llias et al., 2009) 
The model presented by (Xiao \& Dasgupta, 2002) to measure each content, accuracy, format, ease of use, and timeliness is to measure the satisfaction of users of human resource information systems. The measurement model can be seen in the above figure. Measurements were carried out with 12 questions for each variable. Content variable with questions whether the system provides the required information, whether the system provides reports exactly as needed, and whether the system provides sufficient information.

Accuracy variables with the question of whether the system is accurate and whether you are satisfied with the accuracy of the system in a useful format. Next, is the Format variable with the question of whether the output produced is in a useful format and is the information clear? Ease of Use variable with the question: Is the system easy to use, user-friendly, and easy? While the Timelines is an independent variable, Do you get the information you need and provide up-to-date information.

The development of the model was further developed by (Sugianto \& Tojib, 2006) by adding two variables, namely confidentiality and security, the authors' previous research as well. Privacy is the claim of individuals to be left alone, free from surveillance or interference from other individuals, organization, or the state (Bowen et al., 2013). Privacy is the claim of individuals to be left alone, free from the supervision or interference of other individuals, organizations, or countries. Users will feel more happy and satisfied if a personal information system is confidential. So the higher the privacy, the higher the level of satisfaction.

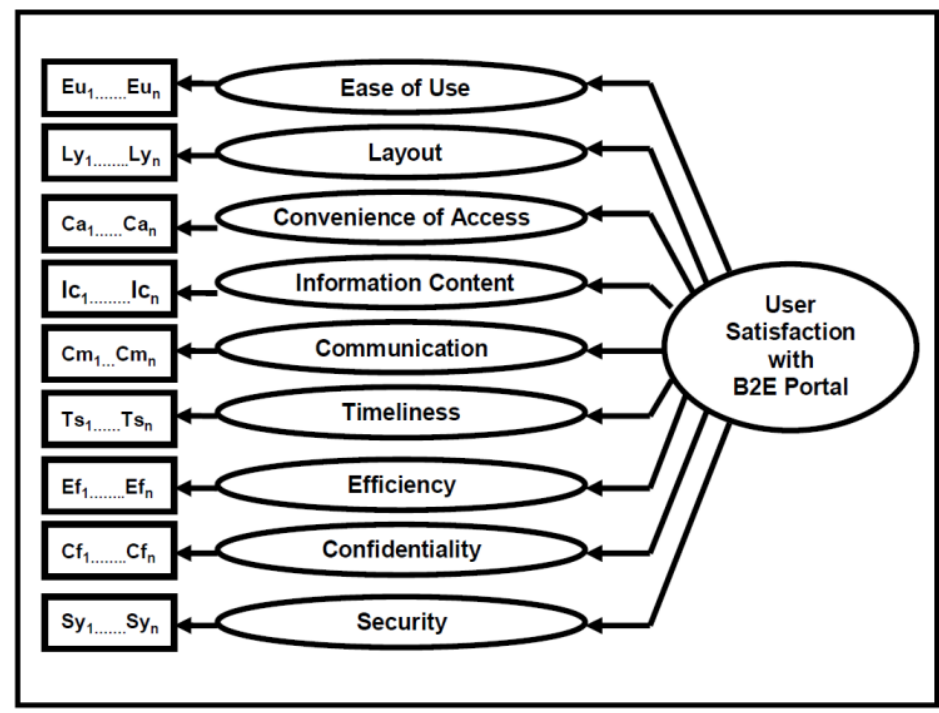

Figure 4: Model Development of User Satisfaction of Information System (Sugianto \& Tojib, 2006)

The picture shows two addition variables to previous model, secure and confident. The security means that the system has policy and procedure. The system must be also provide tools or instrument that used to prevent such as unauthorized access, alteration, thef, or physical damage to information system state. Security is free for replacement, theft, or physical damage to the state of the information system (Sugianto \& Tojib, 2006). Fitting that the higher the security of a system, the greater the satisfaction of its users.

According to (Birnhack et al., 2014) privacy is an indicator of a mindset other than technology or a technology mindset. Privacy is mentioned as data protection, for example, employee data in HRIS is safe and does not come out scattered everywhere if it is not controlled by a secure system and authorization. Likewise, security is the ability to maintain the security of the technology itself. 


\section{c. Quality and Information of System Usage Model}

A successful system is then developed with indicators of system quality and information quality. If the two indicators, namely if the use increases, satisfaction with the use will increase. On the other hand, further development was carried out by (Bokhari, 2005) with reference to Delone and McLean as shown in Figure 3 below.

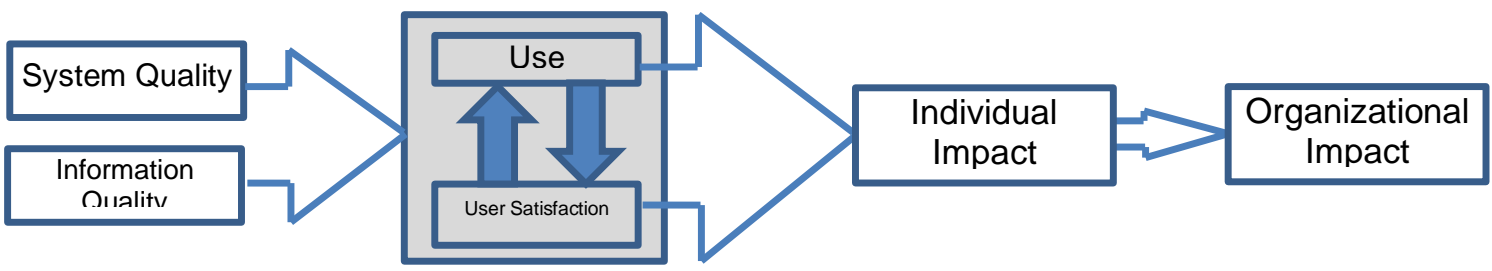

Figure 5: Quality and Information of System Usage Model (Xiao \& Dasgupta, 2002)

The system usage model was later developed by other studies, namely by linking a successful system with decision making through the quality of information systems so that information is used (system usage) which affects individuals and organizations (Xiao \& Dasgupta, 2002). Data from the information system is also selected and through the process of information systems human resources are used. The development is also seen from the use of information systems through the acceptance of information systems. The use of the system and the desire to use is the use of the system (system usage). The system usage is also an implementation of the human resource information system.

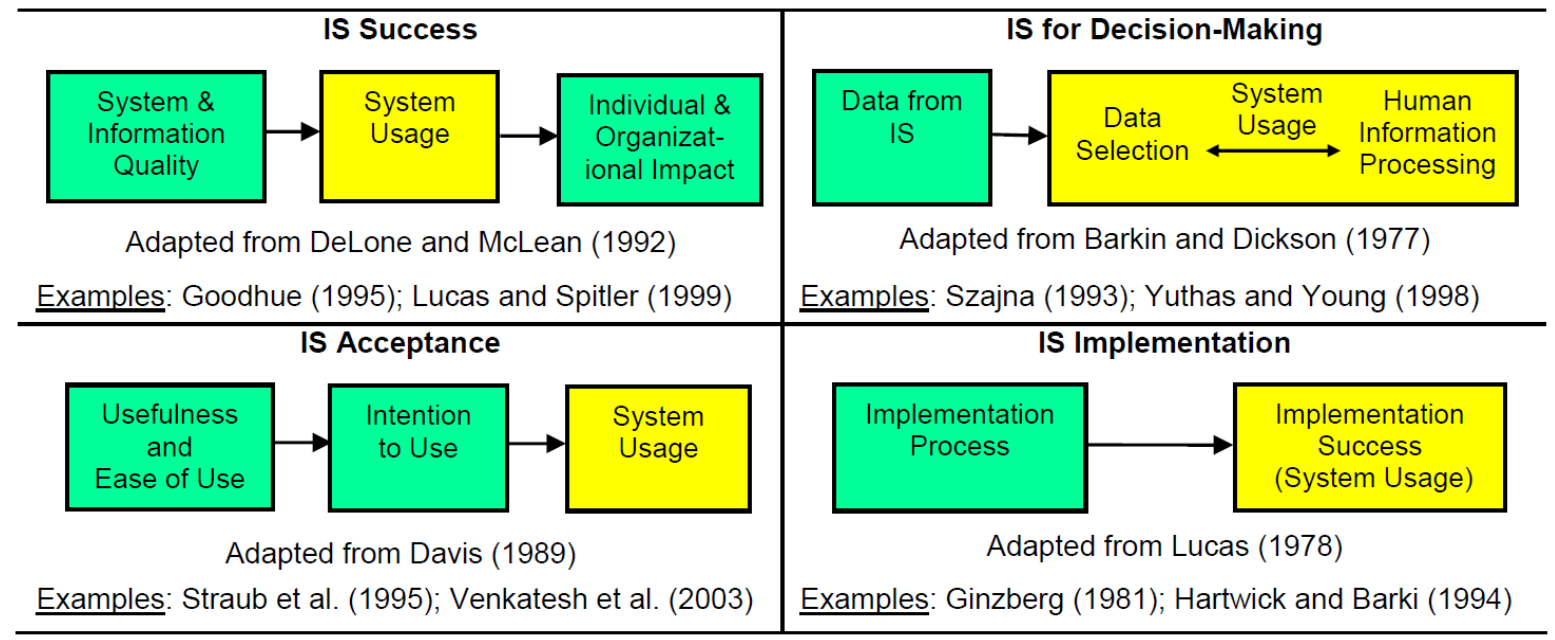

Figure 6: The Development of System Usage Model (Xiao \& Dasgupta, 2002).

\section{d. Information System Effectiveness Model}

Actually this capital was developed from the model of system use and information system satisfaction from Delone and McLean (McLean \& William, 1978), (Torkzadeh's, 2010b), and (Haines \& Petit, 1997)and as well as in research of (Sugianto \& Tojib, 2006)with the main variables being information quality, system quality, and system usage (user satisfaction) which are the measurement of the effectiveness of information systems. The data taken is based on the perception of the user and the attitude of the user and the actual use of the information system in question. and the dimensions and measurements of the three variables can be seen as follows 


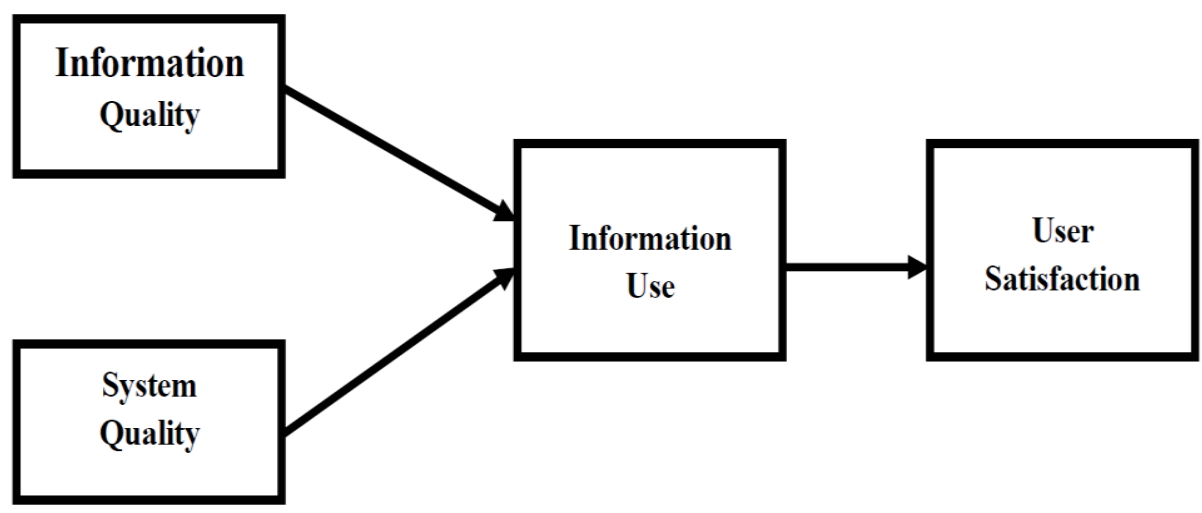

Figure 7: Information System Effectiveness (Hosnavi \& Ramezan, 2010)

Based on the above model can be explained as follows. First, measuring information quality focuses on the output produced by the system and the value, usefulness or relative importance associated with it by the user. Therefore, most measures are perceptual. Bailey and Pearson identified nine characteristics of information quality including: accuracy, precision, currency, timeliness of output, reliability, completeness, conciseness, format and relevance and these started a stream of research in user satisfaction Bailey and Pearson (Bailey \& Pearson, 1983). Other researchers added criteria such as understanding (Wahyuningsih et al., 2014) the service to user for human resource information system satisfaction (Srivastava et al., 2021) usefulness of reports by Mahmood and Jeanette (Hosnavi \& Ramezan, 2010), adequacy, freedom from bias, comparability and quantitative (King and Barry, 1983).

Second, the use of information (system use) is measured using the Technology Acceptance Model (TAM). This model was presented by Davis (Erdoğmu \& Esen, 2011) (Rosna \& Toin, 2016) and presented below in Figure 6. TAM is derived from the theory of reasonable action, a model related to determining behaviour that is in accordance with consciousness. Action theory that underlies the consideration that beliefs influence attitudes, which lead to intentions, and then produce behaviour. TAM assumes that beliefs about usability and ease of use are always the main determinants of IT/IS adoption in organizations. According to TAM, these determinants form the basis of the attitude of using a particular system, which secondly determines the intention to use, and then results in actual usage behaviour. Perceived usefulness is defined as the degree to which a person believes that using the system will improve job performance. Perceived ease of use refers to the extent to which a person does not believe that using the system will be free from mental effort (R. E. Indrajit, 2006).

Third, system quality usually focuses on the performance characteristics of the system under study. Several studies found resource utilization and investment utilization (Kriebel and Raviv), accuracy, processing speed, response time, easy access, easy use, friendly work environment, and the latest technology in hardware and software, system (Panigyrakis \& Chatzipanagiotou, 2006). Hamilton and Chervany's list of system quality measures is perhaps the best known: data currency, response time, turnaround time, data accuracy, reliability, completeness, system flexibility and ease of use (Hamilton and Chervany, 1981). More recently, Seddon considered system quality to be related to "bugs" in the system (system reliability), user interface consistency, ease of use, documentation quality, and program code quality and maintainability (Seddon, 1997).

Fourth, user satisfaction (user satisfaction). Measurement of user satisfaction is as described in the previous user satisfaction model using the methods and models used by (Torkzadeh's, 2010b). 


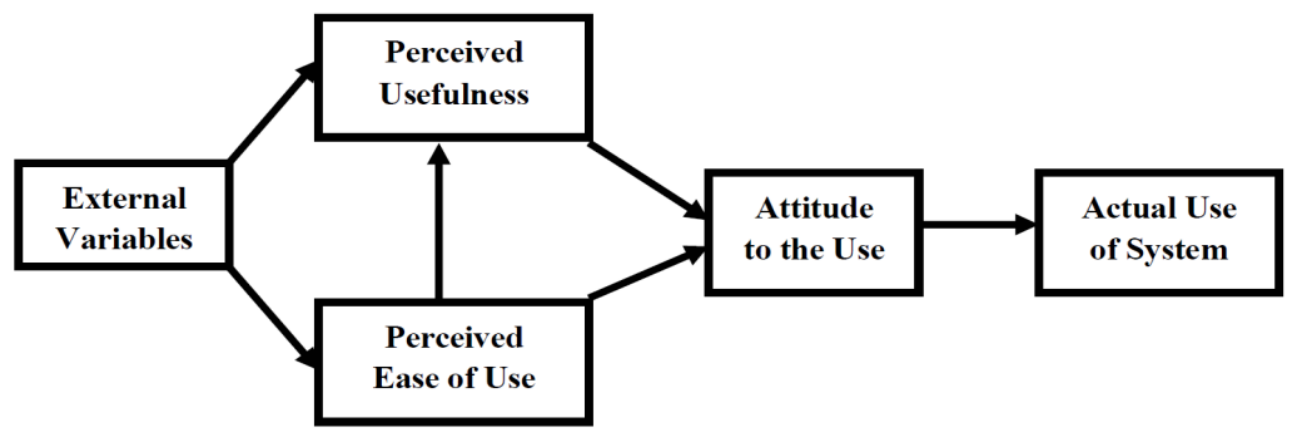

Figure 8: Technology Acceptance Model (TAM (Torkzadeh's, 2010b).

Information system effectiveness model by measuring information quality, system quality, and system use is measured by previous user satisfaction model and technology readiness model. The concepts, dimensions, and measurements as described previously are as follows:

\begin{tabular}{|c|c|c|}
\hline Concept & Dimensions & Measures \\
\hline \multirow{3}{*}{$\begin{array}{l}\text { Information } \\
\text { System } \\
\text { Effectiveness }\end{array}$} & Information Quality & $\begin{array}{c}\text { Information Accuracy } \\
\text { Information Preciseness } \\
\text { Information Completeness } \\
\text { Information Timeliness } \\
\text { Information Compatibility } \\
\text { Information Understandability } \\
\text { Information Volume Appropriateness }\end{array}$ \\
\hline & System Quality & $\begin{array}{c}\text { Limitation of Unauthorized Access } \\
\text { Ease of System Use } \\
\text { Presenting Integrated Reports } \\
\text { Time of Response } \\
\text { Changeability in the System Conditions } \\
\text { Preventing from Program Interruption }\end{array}$ \\
\hline & System Use & $\begin{array}{c}\text { Job Performance Improvement } \\
\text { Goal Achievement } \\
\text { Flexible Interaction with System } \\
\text { Ease of Doing Tasks with Using System } \\
\text { Clear and Understandable Interaction with System } \\
\text { Productivity Improvement with Using System } \\
\text { Ease of Requesting from System }\end{array}$ \\
\hline
\end{tabular}

\section{PROPOSE MODEL}

\section{a. Previous Study}

The previous research by (Haines and Petit 1997) regarding the requirements for the success of a human resource information system, using a simple but inclusive proposition consisting of three sets of antecedents, namely (1) user satisfaction and system usability 
(individually/task, organizational, system) and the two dependent variables (user satisfaction) and system usage.

Furthermore, eleven variables are estimated to affect user satisfaction and system use in terms of system conditions. The eleven variables included in the system requirements are grouped as (a) the delivery system, (b) system functioning, and (c) system performance. The delivery system variables start from technical issues to human factors. The eleven variables are involvement, training, support, documentation, and application development. In previous studies, the strength of the relationship between user satisfaction and system usage was not clearly explained. However, this study expects user satisfaction to use more systems. The correlation between the two dependent variables looks weak. Therefore, this study confirms that a higher level of user satisfaction does not mean using the system more.

There are several studies to support research and strengthen the concept of Doll and Torkzadeh, such as that conducted by (Ilias et al., 2009) where they measure the level of satisfaction with the instrument that has been carried out by Doll and Torkzadeh thus strengthening the concept.

\section{b. Digital Mindset vs the effectiveness of human resource information management}

As previously stated, the research discussion to see the impact of the digital mindset on the management of human resource information was carried out with two approaches, observations of the behaviour of users of human resource information system and the results of previous studies related to the mindset of digitizing human resource management. Digitization itself can affect the management of human resources, especially human resource information systems (Donaghue, 2010).

If explained by the results of Birnhack's research (Birnhack et al., 2014), the conditions in an organization that are currently obedient to the existing system or SOP, then the factors mentioned by Birnhack are the legal factor being important while the privacy factor is automatically due to confidentiality in every large organization. or the government, especially banking, it is very important to maintain, both the secret of the position and the secret of stakeholders such as respondent data, data on bank funds at Bank Indonesia.

Based on review research models and research on user satisfaction on human resource information systems, as shown in the model can be conclude as follows:

1. The combination model (Haines \& Petit, 1997) and updated by (Torkzadeh's, 2010b) and (DeLone \& McLean, 1992) are to produce a model associated with the digitization of I/S.

2. Digitization of information systems is a technology to speed up the process of providing information systems for improving individual and company performance. The digitization process occurs when the digital mindset changes to a digital mindset.

3. A quality information system will be possible if digitization and digitization occurs if the formation of digital behaviour and thoughts or digital mindset. Likewise, the quality of the system is very dependent on the existence of system digitization. If the existing system is not supported by digital, the system will be slow and hinder the flow of information

4. The measurement of the effectiveness of the human resource information system is carried out through the perceived value and by using the technology acceptance model.

5. Based on the previous description, we can develop a new model to measure the effectiveness of the human resource information system in the form of an integrative capital by looking at all the dependent and independent variables to form a new model to be proven empirically. This large model consists of variables of information quality, system quality, digital mindset, system usage that affect user perceptions and the effectiveness (success) of information systems. As previous research, two dependent variables are related to each 
other. This relationship will be seen from the SEM modeling, while the earlier variables were measured by survey.

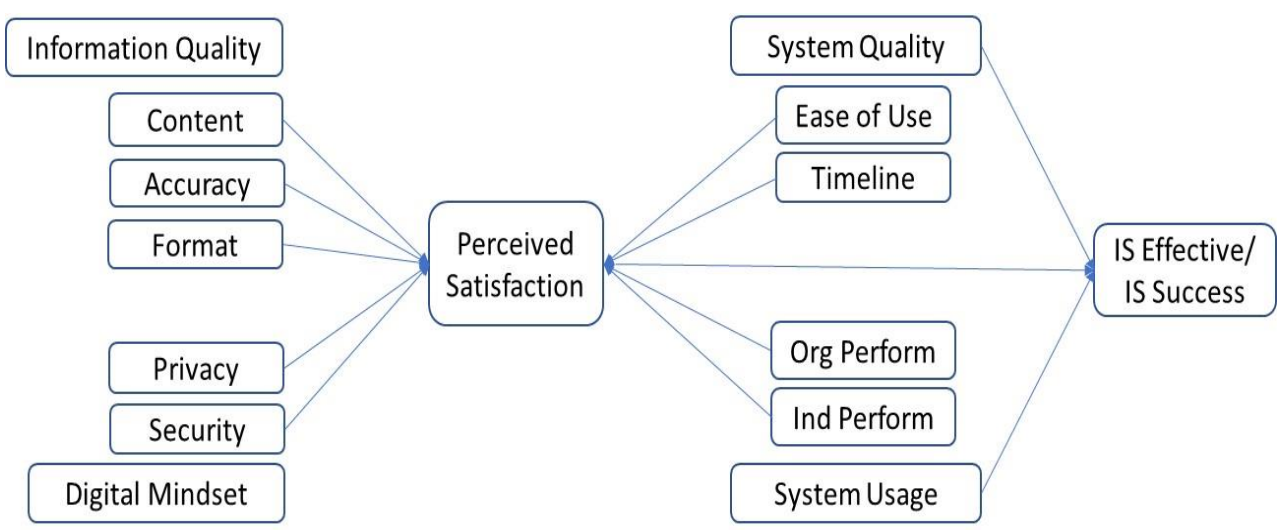

Picture 10: Proposed Model

In the above-proposed model, we can derive some hypotheses for the very next conducting an empirical study to prove the effectiveness and efficiency through human resource information system (HRIS) as a novelty to research as follow:

a. Information quality, system quality, system usage are interdependent, and each has an interrelation and effect in providing effectiveness of HRIS.

b. The digital mindset will positively or negatively relate to the privacy and security of HRIS

c. Information quality is depended on the content, accuracy, format, privacy, and security.

d. Information quality is also dependent on the perceived user satisfaction on information quality to achieve information effectiveness or information success.

e. Organization performance and individual performance indicates system usage

f. Ease of use and timeline in using HRIS means the quality of HRIS

g. All variables, its own alone or altogether, affected HIRIS success. 


\section{REFERENCE}

Afolayan, A., \& Falola, T. (2017). The palgrave handbook of African philosophy. The Palgrave Handbook of African Philosophy, July, 1-867. https://doi.org/10.1057/978-1137-59291-0

Agarwal, R., \& Prasad, J. (1998). A Conceptual and Operational Definition of Information Technology. Information Systems Research, 9(2).

Arrow, K. J. (1969). Classificatory notes on the production and transmission of technological knowledge. In American Economic Review (Vol. 59, Issue 2, pp. 29-35).

Bailey, J. E., \& Pearson, S. W. (1983). Development of a Tool for Measuring and Analyzing Computer User Satisfaction. Management Science, 29(5), 530-545. https://doi.org/10.1287/mnsc.29.5.530

Bakke, A., Myrtveit, I., \& Stensrud, E. (2008). Measurement Of User Satisfaction With Enterprise Portals : An Empirical Study. Proceedings of the Norwegian Informatics Conference (NOKOBIT: Norsk Konferanse for Organisasjoners Bruk Av Informasjonsteknologi) 2008, 1-12. http://www.nik.no/2008/

Birnhack, M., Toch, E., \& Hadar, I. (2014). Privacy Mindset, Technological Mindset. SSRN Electronic Journal, 55(1), 55-114. https://doi.org/10.2139/ssrn.2471415

Bokhari, R. H. (2005). The relationship between system usage and user satisfaction: A metaanalysis. Journal of Enterprise Information Management, 18(2), 211-234. https://doi.org/10.1108/17410390510579927

Bowen, B. D., Bowen, E. E., Headley, D. E., Küçükönal, H., \& Wildt, C. T. (2013). An Innovative Leadership Effectiveness Measure: Applied Analytic Indicators of HighConsequence Industry Performance. Procedia - Social and Behavioral Sciences, 75, 209-216. https://doi.org/10.1016/j.sbspro.2013.04.024

Bukht, R., \& Heeks, R. (2018). Defining, conceptualising and measuring the digital economy. International Organisations Research Journal, 13(2), 143-172. https://doi.org/10.17323/1996-7845-2018-02-07

Carolina, Y. (2015). Towards Ais Success And Its Implications To Information Quality And User Satisfaction. Africa's Potential for the Ecological Intensification of Agriculture, $13(7), 41$.

Çelo, E., \& Dumi, A. (2013). The Leadership Role of Teacher and Re-Dimensioning of Knowledge. Procedia - Social and Behavioral Sciences, 75, 62-70. https://doi.org/10.1016/j.sbspro.2013.04.008

DeLone, W. H., \& McLean, E. R. (1992). Information systems success: The quest for the dependent variable. Information Systems Research, 3(1), 60-95. https://doi.org/10.1287/isre.3.1.60

DeLone, W. H., \& McLean, E. R. (2004). Measuring e-commerce success: Applying the DeLone and McLean Information Systems Success Model. International Journal of Electronic Commerce, 9(1). https://doi.org/10.1080/10864415.2004.11044317

Donaghue, K. (2010). Measuring the effect of guidelines. Pediatric Diabetes, 11(2), 83-84. https://doi.org/10.1111/j.1399-5448.2010.00651.x

Edwin Mansfield. (1975). International Technology Transfer, Form, Resource Requirements, and Policies.pdf.

Erdoğmu, N., \& Esen, M. (2011). An investigation of the effects of technology readiness on technology acceptance in e-HRM. Procedia - Social and Behavioral Sciences, 24, 487495. https://doi.org/10.1016/j.sbspro.2011.09.131 
Haines, V. Y., \& Petit, A. (1997). Conditions for successful human resource information systems. Human Resource Management, 36(2), 261-275. https://doi.org/10.1002/(SICI)1099-050X(199722)36:2<261::AID-HRM7>3.0.CO;2-V

Hall, D. L., \& Frcpc, F. (2012). Reproduced with permission of the copyright owner . Further reproduction prohibited without. Journal of Allergy and Clinical Immunology, 130(2), 556.

Hellstén, S.-M., \& Markova, M. (2003). The DeLone and McLean Model of Information Systems Success - Original and Updated Models. Journal of Management Information Systems, 19(4), 9-30.

Hosnavi, R., \& Ramezan, M. (2010). Measuring the effectiveness of a human resource information system in National Iranian Oil Company: An empirical assessment. Education, Business and Society: Contemporary Middle Eastern Issues, 3(1), 28-39. https://doi.org/10.1108/17537981011022797

Ilias, A., Abd Razak, M. Z., Rahman, R. A., \& Yasoa', M. R. (2009). End-User Computing Satisfaction (EUCS) in Computerised Accounting System (CAS): Which the Critical Factors? A Case in Malaysia. Computer and Information Science, 2(1), 18-24. https://doi.org/10.5539/cis.v2n1p18

Indrajit, Prof. R. E. (2016). Konsep Dasar Sistem dan Teknologi Informasi. Sistem Dan Teknologi Informasi, 5.

Indrajit, R. E. (2000). Pengantar Konsep Dasar Manajemen Sistem Informasi dan Teknologi Informasi. STIMIK PERBANAS Renaissance Center, 10, 276.

Indrajit, R. E. (2006). Electronic Government Konsep Pelayanan Publik Berbasis Internet dan Teknologi Informasi. XIX, 1-93.

Ives, B., Olson, M. H., \& Baroudi, J. J. (1983). The Measurement of Satisfaction User Information. Communications of the ACM, 26(10), 785-793.

Kulviwat, S., Bruner, G. C., Kumar, A., Nasco, S. A., \& Clark, T. (2007). Toward a unified theory of consumer acceptance technology. Psychology and Marketing, 24(12), 10591084. https://doi.org/10.1002/mar.20196

Lei, Z., \& Jing, Y. (2016). Study on Human Resource Reform in the Digital Transformation. https://doi.org/10.2991/jimec-16.2016.84

Lim, K., Lim, J.-S., \& Heinrichs, J. H. (2008). Validating an End-User Computing Satisfaction Instrument: A Confirmatory Factor Analysis Approach Using International Data. Journal of International Technology and Information Management, 17(2), 153165.

MacKenzie, D., \& Wajcman, J. (1965). The Social Shaping of Technology.

Madeuf, B. (1984). International technology transfers and international technology payments: Definitions, measurement and firms' behaviour. Research Policy, 13(3), 125-140. https://doi.org/10.1016/0048-7333(84)90021-0

Madhuchhanda, M., \& Kumar, S. T. (2009). HRIS in the Indian scenario: A case study of a large organization. South Asian Journal of Management, 16(2), 127-168.

Maskus, B. K. E. (2004). Encouraging International Technology Transfer. 7.

McLean, W. H. D. A. E. R., \& William. (1978). The DeLone and McLean Model of Information Systems Success : A Ten-Year Update. Developmental Biology, 66(2), 442456. https://doi.org/10.1016/0012-1606(78)90250-6

Meyer, M. W. (2003). Training of sports skills (coaching guidance).

Panigyrakis, G. G., \& Chatzipanagiotou, K. C. (2006). the Impact of Design Characteristics and Support Service on the Effectiveness of Marketing Information System-- An Emprical Investigation (p. 104). 
Ramezan, M. (2010). Measuring the effectiveness of a human resource information system in National Iranian Oil Company: An empirical assessment. Education, Business and Society: Contemporary MiEducation, Business and Society: Contemporary Middle Eastern Issuesddle Eastern Issues, 3(1), 28-39. https://doi.org/10.1108/17537981011022797

Reddy, P., Sharma, B., \& Chaudhary, K. (2020). Digital literacy: A review of literature. International Journal of Technoethics, 11(2), 65-94. https://doi.org/10.4018/IJT.20200701.oa1

Rosna, D., \& Toin, Y. (2016). Faktor-faktor Yang Mempengaruhi Kepuasan Penggunaan EProcurement oleh Penyedia Barang dan Jasa (Studi Kasus di Pemerintahan Surakarta). 1(1), 16-29.

Savic, D. (2019). From Digitization, through Digitalization, to Digital Tranformation. April.

Skulski, P. (2020). Cultural Aspects of International Business. November.

Srivastava, S., Dev, S., \& Bajaj, B. (2021). Human resource information system use, satisfaction, and success. International Journal of Enterprise Information Systems, 17(1), 106-124. https://doi.org/10.4018/IJEIS.2021010106

Sugianto, L., \& Tojib, D. R. (2006). Modelling User Satisfaction with an Employee Portal. 1(1:2), 239-255. https://doi.org/10.6702/ijbi.2006.1.2.4

Tannenbaum, S. I. (1990). Human Resource Information Systems: User Group Implications. Journal of Systems Management, 41(1), 27-32.

Torkzadeh's, D. and. (2010a). The Computer User Satisfaction Questionnaire and its reduced version, the User Information Satisfaction Short-form edit | edit source. 1988.

Torkzadeh's, D. and. (2010b). The Computer User Satisfaction Questionnaire and its reduced version, the User Information Satisfaction Short-form edit | edit source. 1988.

Wahyuningsih, S., Fitri, S., \& Komalasari, G. (2014). GAYA KEPEMIMPINAN PEREMPUAN (Studi Pada Ketua OSIS diSMA Se-Jakarta Timur). INSIGHT: JURNAL BIMBINGAN KONSELING, 3(2). https://doi.org/10.21009/insight.032.19

Woolgar, S. (1985). Why not a Sociology of Machines? The Case of Sociology and Artificial Intelligence. 1985.

Xiao, L., \& Dasgupta, S. (2002). Measurement of user satisfaction with web-based information systems: An empirical study. Proceedings of the Eighth Americas Conference on Information Systems: Human-Computer Interaction Studies in MIS, 1149-1155.

Yahaya, M., Al-Khawlani, M. A. A., Suleiman, M. S., \& Usman, U. M. Z. (2018). Organizational structure and an effective communication: the moderating effect of transformational leadership. International Journal of Scientific and Technology Research, 7(11), 4-9. 